\title{
Adverse Event End Date Time
}

National Cancer Institute

\section{Source}

National Cancer Institute. Adverse Event End Date Time. NCI Thesaurus. Code C83201.

The date and time an adverse event has concluded. 